Guest Editorial, part of a Special Feature on The influence of human demography and agriculture on natural systems in the Neotropics

\title{
Globalization and Land-Use Transitions in Latin America
}

\author{
$\underline{\text { H. Ricardo Grau }}^{1,2}$ and $\underline{\text { Mitchell Aide }}^{3}$
}

\begin{abstract}
Current socioeconomic drivers of land-use change associated with globalization are producing two contrasting land-use trends in Latin America. Increasing global food demand (particularly in Southeast Asia) accelerates deforestation in areas suitable for modern agriculture (e.g., soybean), severely threatening ecosystems, such as Amazonian rain forests, dry forests, and subtropical grasslands. Additionally, in the coming decades, demand for biofuels may become an emerging threat. In contrast, high yields in modern agricultural systems and rural-urban migration coupled with remittances promote the abandonment of marginal agricultural lands, thus favoring ecosystem recovery on mountains, deserts, and areas of poor soils, while improving human well-being. The potential switch from production in traditional extensive grazing areas to intensive modern agriculture provides opportunities to significantly increase food production while sparing land for nature conservation. This combination of emerging threats and opportunities requires changes in the way the conservation of Latin American ecosystems is approached. Land-use efficiency should be analyzed beyond the local-based paradigm that drives most conservation programs, and focus on large geographic scales involving long-distance fluxes of products, information, and people in order to maximize both agricultural production and the conservation of environmental services.
\end{abstract}

Key Words: agriculture; deforestation; ecological transition; forest transition; globalization; land-use change; Latin America

\section{LAND-USE CHANGE IN A GLOBALIZED WORLD}

The anthropogenic environmental impacts between 1950 and 2050 are likely to be the most severe in human history. During these hundred years, the world population will increase from approximately 2.5 billion in 1950 to more than 9 billion in 2050, due to the highest population growth rates in history. But, by the end of this period, the human population is expected to approach a plateau or even begin declining, something that has never happened in historical times (Lutz et al. 2001, United Nations Population Division (UNPOP) 2003). Both the acceleration and the later decrease in population growth reflect another novel process: on average, humans have never been so affluent, healthy, and well fed.

This wealth is in part the result of an unsustainable exploitation of global natural resources, particularly fossil fuels and the conversion of natural systems. The dependence of the global economy on fossil fuels has resulted in an increase in greenhouse gases and rising global temperature (Intergovernmental Panel on Climate Change (IPCC) 2007). The other major impact has been the appropriation of global primary productivity (Vitousek et al. 1986, Foley et al. 2007) resulting from the conversion of nearly $35 \%$ of terrestrial ecosystems to agricultural lands. Both processes can have enormous impacts on ecosystems. Although our use of fossil fuels continues to increase, changes in population and economy are producing two contrasting trends in land use. On the one hand, the continuing increase in the human population and per capita consumption, and the changes in diet are increasing global demand for food, which is the main driver of agricultural expansion. The major consequences of the conversion of natural ecosystems into agricultural lands are the loss of biodiversity and other ecosystem services (Dirzo and Raven 2003, 
Millennium Ecosystem Assessment (MEA) 2005). On the other hand, through genetic improvements, and the use of fertilizers, pesticides, and fossil fuels, modern agriculture has greatly increased yields, thus reducing the area that is directly impacted by agriculture (Smil 2000). The concentration of modern agriculture on the most productive soils ("agriculture adjustment," Mather and Needle 1998) has favored the abandonment of marginal agriculture and recovery of forests in many countries ("forest transition," Mather 1992, Rudel et al. 2005), and is contributing to reducing deforestation rates in the developing world (Balmford et al. 2005).

Current global environmental changes are no longer the simple addition of local or regional effects. Instead, many of the drivers of changes are the longdistance connections that involve fluxes of matter, energy, and information among countries, regions, and continents. In addition, the spatial distribution of the human population is changing. In 2008, for the first time in human history, the global urban population has exceeded the rural population. This migration to the cities has been accompanied by international migration and a dramatic increase in remittances to migrants' homelands, which can have enormous effects on local economies (The World Bank 2006). Furthermore, the rapidly growing economies of China, India, and other countries in Southeast Asia have greatly accelerated the flow of natural resources and goods around the world.

How will these processes affect agricultural lands and natural ecosystems in Latin America? To answer this question we need to focus on two scales of drivers: local and global. The present population in Latin America is approximately 500 million, and it is expected to increase by $50 \%$ by 2050 . In addition, per capita consumption in Latin America is below the level of the developed world, and one can expect that it will continue to increase as the region's economy grows. Thus, a major challenge is to determine how to meet the increasing food needs of this growing population without destroying the remaining natural ecosystems. Furthermore, Latin America includes extensive plains with fertile soils, with comparatively low production costs. These ecosystems not only feed the local population, but also produce an increasing amount of food for the rest of the world, in particular for Southeast Asia where the population and per capita consumption are increasing rapidly, and where growing income is promoting diet changes toward a higher consumption of animal protein. The fate of Latin American ecosystems will depend on how economic and social forces influence where and how the growing Latin American population lives in the coming decades and how the region responds to the global changes in population, trade, consumption, and technology.

\section{DEFORESTATION AND ECOSYSTEM RECOVERY IN LATIN AMERICA}

Deforestation continues to be the dominant land-use trend in Latin America (Fig. 1) (Ramankutty and Foley 1999, Achard et al. 2002), and subsistence agriculture, an important part of many local economies, is one of the major contributors (Chowdhury and Turner 2006, Pan et al. 2007). But, socioeconomic changes related to globalization are promoting a rapid change toward agricultural systems oriented to local, regional, and global markets. The Amazon basin is the region that has lost the largest area to deforestation, and where deforestation has had the greatest impact on biodiversity and biomass loss (Houghton et al. 1991, Laurance 1998, Lambin et al. 2003), but most other biomes have also been and continue to be severely affected by conversion to agriculture and pastures (e.g., Ellenberg 1979, Sader and Joyce 1988, Viña and Cavelier 1999, Galindo-Leal and De Gusmao Camara 2003, Klink and Machado 2005, Viglizzo et al. 2006, Gasparri et al. 2008). Historically, traditional shifting agriculture and cattle ranching, often favored by government subsidies and migration policies, have been the main drivers of deforestation in the Amazon, as well as in other ecosystems in Latin America such as the Andean forests, Central American lowlands, and South American dry forests (Hecht 1993, Kaimowitz 1995, Grau et al. 2008a). Although these driving forces continue to act in many places, exportoriented industrial agriculture has become the main driver of South American deforestation. In Brazil, Bolivia, Paraguay, and Argentina, extensive areas of seasonally dry forest with flat terrain and enough rainfall for rain-fed agriculture are now being deforested for soybean production, which is mainly exported to China and the European Union (Dros 2004). This process affects the species-rich Amazon forests (Fearnside 2001, Killeen et al. 2008) and indirectly favors other forms of degradation beyond the agriculture frontier, such as logging and fire (Nepstad et al. 1999). The expansion of modern 
agriculture is having its greatest effects on the two most threatened biomes both at global and continental scales (Hoeckstra et al. 2005): tropical and subtropical dry forests (Zak et al. 2004, Grau et al. 2005, Silva et al. 2006) and temperate grasslands and savannas (Paruelo and Oesterheld 2003, Baldi and Paruelo 2008). Although the "soy boom" in Latin America is an important threat to the region's biodiversity, it has brought large economic benefits to the economy sectors associated with production, transportation, commercialization, and processing of agricultural products and to the local and national governments through taxes. Furthermore, the "soy boom," partly based on transgenic cultivars, is supplying cheap calories and high-quality protein to help meet the growing demand for food in Southeast Asia, and is thus contributing to increasing nutrition levels in this region.

Although the efficiency of modern agriculture and the associated lower food costs are positive for consumers, smallhold farmers, particularly those on marginal lands, are frequently unable to compete with large-scale agriculture. This process and the increase in off-farm jobs in the service and industry sectors in the cities stimulate rural-urban migration. The combination of agricultural modernization and rural-urban migration often leads to a shift in the mode of food production and the abandonment of marginal agricultural and grazing land, which can favor ecosystem recovery both as spontaneous processes and by facilitating the implementation of protected areas or conservation policies (Mather and Needle 1998, Mather 2001, Aide and Grau 2004, Grau and Aide 2007, Izquierdo and Grau 2008). Forest transition or more generally, ecological transition (ecosystem recovery occurs also in nonforested biomes), occurs when an economy shifts toward non-agricultural production, agriculture concentrates in the most productive lands, and marginal agriculture is abandoned, favoring the recovery of forests and other natural ecosystems. Although comparatively less important than deforestation and much less perceived by the general public and the scientific community, processes of ecosystem recovery can be observed in many Latin American areas (Fig. 1). Forest expansion or recovery of degraded forests during recent decades has been reported for several Caribbean and Central American areas in association with the strong impact of rural outmigration and economic modernization, including Puerto Rico (Lugo 2002, Grau et al. 2003, Parés Ramos et al. 2008), Dominican Republic
(Grau et al. 2008c), Mexico (Klooster 2003, Bray and Klepeis 2005), El Salvador (Hecht et al. 2006), Honduras (Southworth and Tucker 2001), Costa Rica (Kull et al. 2007), and Panama (Wright and Samaniego 2008). In South America, examples of ecosystem recovery include forest expansion in peri-urban ecosystems (Baptista 2008, Grau et al. 2008b), expansion of Andean forests into grasslands (Grau 1985, Kitzberger and Veblen 1999), and landuse disintensification in deserts and semi-arid ecosystems (Moran et al. 1996, Preston et al. 1997, Wiegers et al. 1999, Morales et al. 2005, Jepson 2005, Grau et al. 2008a).

Although agriculture is being abandoned in some marginal areas, in other areas it continues to expand; for example, in regions used for illegal crops. Compared with modern agriculture, which concentrates in fertile and flat soils, illegal crops are often cultivated in marginal areas, mainly because of poor accessibility, which reduces legal controls. The most common of these areas in Latin America are the humid slopes of the Andes, where cultivation of coca and opium are a major source of deforestation and environmental degradation (Cavelier and Etter 1995, Fjdelsa et al. 2005, Bradley and Millington 2008). These areas are also affected by armed conflicts and are outside the legal system of the country, a situation with two contrasting consequences for conservation. On the one hand, social and economic deterioration may lead to outmigration and land abandonment, but on the other hand, conditions for establishment of protected areas and legal enforcement of conservation become very difficult.

\section{OPPORTUNITIES AND THREATS}

Latin America, particularly South America, has had the luxury of being a large continent with a comparatively small population, of which a large proportion lives in urban centers (approximately $80 \%$ in South America). The relatively small area occupied by urban areas and the low rural population density have permitted highly inefficient land-use practices that have significantly reduced or transformed natural ecosystems. In particular, extensive areas of tropical forest have been converted to pastures for low-density domestic grazers or low-productivity agricultural systems (Fig. 2). To accommodate the growth of an additional 250 million people in Latin America in the next 40-50 years, urban areas and agricultural 
Fig. 1. Map of Latin America main biomes (based on Eva et al. 2004), showing the main deforestation fronts (in red, based on Food and Agriculture Organization (FAO) 2003, Gasparri et al. 2008), and selected case studies of ecosystems regeneration (in blue).

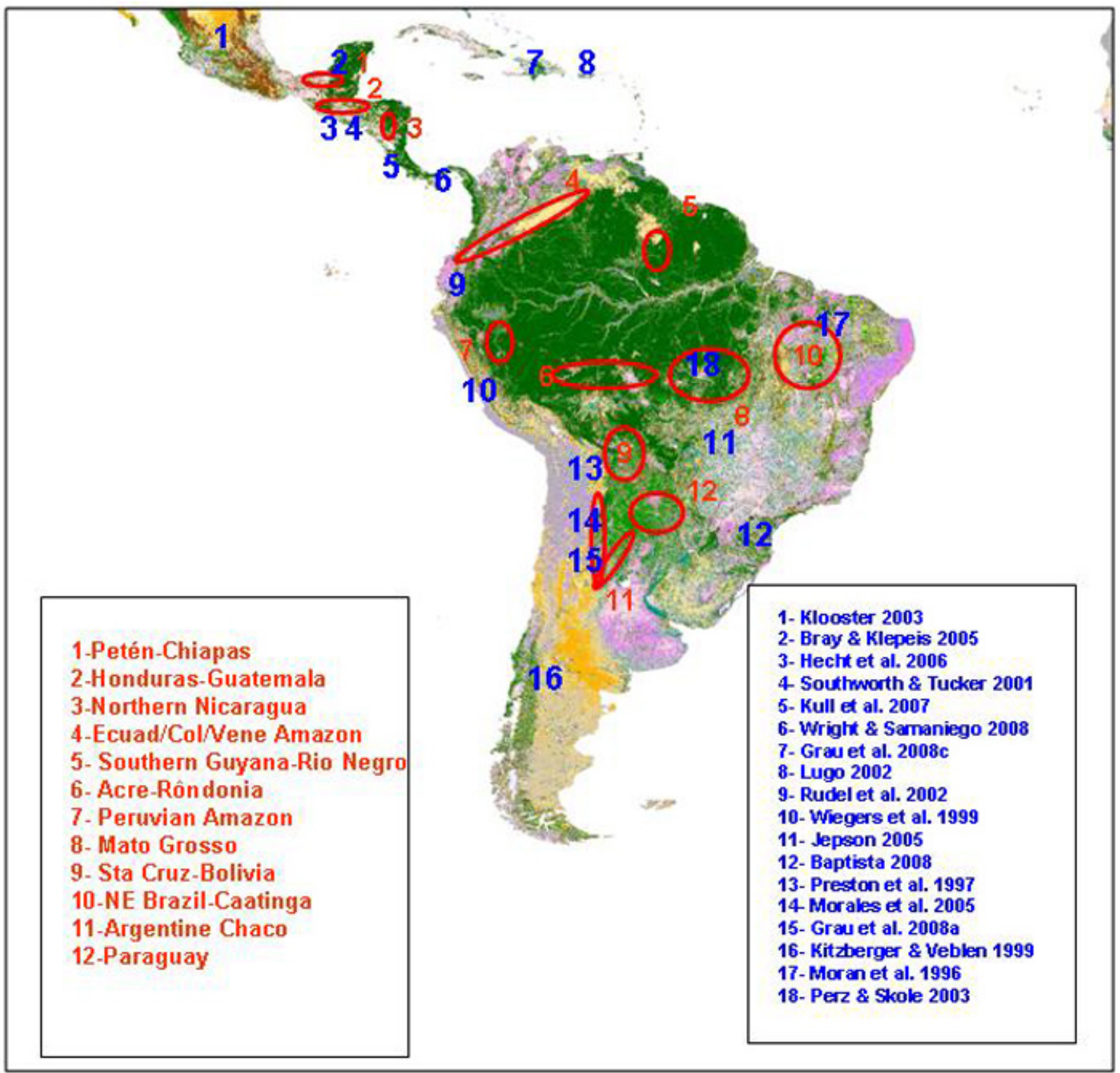


lands will inevitably increase; therefore, to maintain the high levels of biodiversity that characterize many of the ecosystems of Latin America, landscapes and regions must be used in a more efficient way.

Land-use change is driven by a complex myriad of actors and processes (e.g., Baptista 2008, Bradley and Millington 2008, Fearnside 2008, Izquierdo et al., 2008, Killeen et al. 2008, Padoch et al. 2008), but a large part of their effects in terms of land-use efficiency is reflected in a comparatively simple conflict between food production and conservation of natural and semi-natural ecosystems (Waggoner and Ausubel 2001, Balmford et al. 2005, Green et al. 2005, Grau et al. 2008a). In part, this conflict can be managed by using the most productive soils for high-yield crops, and by dedicating areas of low agricultural productivity to the provision of ecosystem services such as biodiversity conservation, watershed protection, carbon sequestration, and recreation. A shift from traditional agriculture and particularly grazing pastures to modern agriculture represents a large increase in per hectare food productivity (Smil 2000). This shift may imply a major improvement in land-use efficiency to balance conservation and production purposes. For example, in Panama, Wright and Samaniego (2008) found that pastures occupy approximately four times more land than crops, but crops generate 6.7 times greater gross income. In the Chaco dry forests of northern Argentina, Grau et al. (2008a) found that in order to produce the equivalent amount of protein or meat currently produced in the 4.7 million hectares of forests surrounding the "puestos" traditional grazing system, only 16000 or 150000 ha, respectively, would have to be transformed into soybean fields.

Current patterns of rural-urban migration also provide important opportunities to achieve land-use efficiency. Between 1990 and 2000, many rural areas throughout Latin America lost population (Preston 1997). For example, in Mexico $28 \%$ of the municipalities had negative population growth between 1990 and 2000, representing $31 \%$ of the area of Mexico. Although the populations of all Latin America countries are increasing, regions within many countries are losing population due to rural-urban migration. In some cases, rural outmigration may promote environmental degradation by reducing the local labor power needed to maintain irrigation and soil conservation systems (Zimmerer 1993, Harden 1996), or may promote less intensive but highly inefficient land uses such as cattle ranching replacing agriculture or sheep grazing (e.g., Preston 1998, Rudel et al. 2002). But, in many cases, outmigration results in land abandonment, particularly in mountain and desert ecosystems, as well as areas with poor soils. Often, these ecosystems are disproportionately important for watershed and biodiversity conservation. Migration to urban centers, frequently in the USA or Europe, is generally associated with remittances to local relatives, who become less dependent on marginal agriculture, further favoring ecosystem recovery. For example, in Mexico and El Salvador there is a positive correlation between the level of remittance and forest recovery (Bray and Klepeis 2005, Hecht and Saatchi 2007). By moving to urban centers, people consume agricultural products that originate in more efficient systems such as mechanized agriculture, planted pastures, and feedlots; and in general, they improve their living conditions in terms of education, health, and services (Polèse 1998). Furthermore, usually within one generation, these immigrants reduce their fertility to levels typical of urban areas, helping to reduce population growth (United Nations Population Fund (UNFPA) 2007).

In summary, although rural-urban migrations are often complex and frequently involve conflictive social adjustments (Preston 1997, Fearnside 2008, Padoch et al. 2008), they represent an important opportunity to combine social and environmental improvements (Aide and Grau 2004, UNFPA 2007, Grau and Aide 2007). As the process of ecological transition is largely associated with the market economy and the free movement of people, goods, and information, it will be enhanced by policies facilitating migration and discouraging noncompetitive production systems. This can even favor ecosystem recovery in parts of severely threatened ecoregions such as the Cerrado, the Atlantic forest or the Chaco dry forests, which include areas that, due to steep slopes or dry climates, are not suitable for modern agriculture. In contrast, ecosystem recovery in marginal lands will be difficult when inefficient systems of production are maintained through subsidies from government or non-governmental organizations (NGOs), and where marginal conditions and external illegal markets provide opportunities for highly profitable illegal crops (e.g., coca, opium, or cannabis).

Although marginal agricultural lands are being abandoned in many regions of Latin America, there 
Fig. 2. Proportion of land covered by different land uses in Central and South America, and Southeast Asia. Source: FAO (2003).

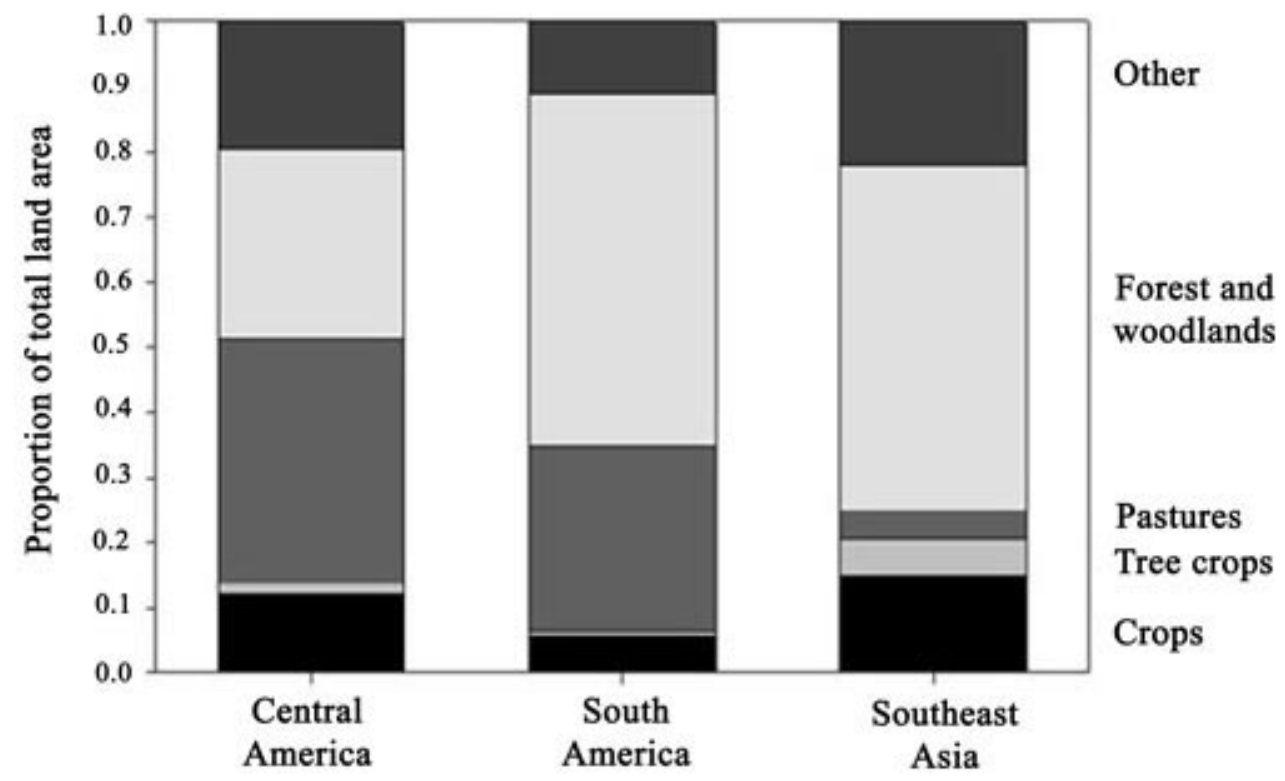

is no guarantee that this will always lead to the recovery of natural ecosystems. For example, secondary forests in peri-urban areas are often dominated by naturalized exotic species (Grau et al. 2003, 2008b, Aragón and Morales 2003, Lugo and Helmer 2004). In many cases, marginal agricultural lands are replaced by exotic tree plantations, as in northeastern Argentina (Izquierdo et al. 2008) or central Chile (Bustamante and Simonetti 2004), or plantation forests may replace non-forested natural ecosystems historically used for grazing (e.g., Nossetto et al. 2005, Farley 2007). Many of the benefits associated with ecological transitions are related to the fact that modern agriculture cannot be carried out in environments that are too dry, too steep, or too infertile. However, some of these barriers could be eliminated or reduced with genetically modified crops (GMCs). Another major concern is the future of biofuels, which could compete for the same areas with natural communities not threatened by conventional agriculture. For example, oil palms can grow in acidic soils, and steep areas of abandoned sugar cane could easily be converted to production for biofuels. Furthermore, next-generation biofuels can be based on grasslands, many of which can be grown under conditions of steeper slopes and drier soils than conventional agriculture. Government subsidies and growing demand for biofuels contribute to increased agricultural prices, and high prices further promote the expansion of agriculture; both in ecoregions that have already experienced significant transformation (southern Amazon, Cerrado, Pampas, Peten, Chaco, and Chiquitano forests), and in others, such as the Llanos of eastern Colombia, Venezuela, and Guyana that include extensive areas of flat terrain and great agricultural potential.

\section{THE CHALLENGE OF BALANCING CONSERVATION AND DEVELOPMENT}

Presently, most conservation policy is largely driven by the assumptions that deforestation and habitat fragmentation processes are ubiquitous and ever expanding, and that market forces generally result in ecosystem degradation. As we have discussed in this paper, these assumptions can be unrealistic. To be successful in protecting the world's biodiversity we need to incorporate major drivers of land-use change, and the need for feeding 
a growing population, as well as recognize that global markets and the free movement of people and products can contribute to improving land-use efficiency. It must be recognized that the globalization process and changing demographic dynamics are shifting the agricultural landscape, and this will have both positive and negative effects for ecosystems and the environmental services they provide in Latin America. Current land-use trends in Latin America include both traditional (cattle ranching, shifting agriculture) and emerging (GMC-based modern agriculture, biofuels) threats, as well as new opportunities derived from ecological transition processes and population urbanization. To understand the relative importance of these factors, the following questions need to be addressed:

1. Global food production: how will the global demand for food products influence the extent and distribution of modern agriculture in Latin America? What will be the consequences of new genetic cultivars (e.g., drought-resistant soybean) that could surmount current environmental limitations for modern agriculture? In addition to the local effects of deforestation, what are the effects of long-term soil degradation and the" off-site" effects of modern agriculture (e.g., soil, water, and atmospheric contamination)? What will be the effect of the competition for soils between agriculture for food and for biofuels? What are the net ecological impacts of locally "environmentally friendly" production systems (e.g., organic agriculture, shade coffee, etc) when their per hectare productivity is taken into account?

2. Non-food crops: how will a shift to biofuels based on sugarcane, oil palms, soybeans, and grasses affect the distribution of natural areas and local economies? To what extent are illegal crops a threat to nature conservation, and what are the global drivers of this threat? Could other (e.g., rubber) non-food agriculture become important in Latin America as the demand from Southeast Asia continues to increase?

3. Demographic changes: will the trend in ruralurban migration continue as the Latin American population grows over the next 4050 years? To what extent does rural-urban migration improve the living conditions of marginal populations and favor the abandonment of inefficient agriculture production? Could Latin America shift from being a source of migrants to Europe and North America to a net attractor of migrants in the coming decades?

4. Ecological transition: what are the trends and rates of ecosystem recovery, and what are the major human and natural drivers of this process at different spatial and temporal scales? To what extent does agriculture abandonment lead to the recovery of natural ecosystems vs. monoculture forest plantations? How will the ecology of the "new" ecosystems resulting from ecological transition, often characterized by abundant exotic species, behave in terms of biodiversity, environmental services, and capacity to "recover" extinction debt? What are the ecological consequences of the interactions between land-use transitions and climate change?

5. Political ecology: what are the most efficient governance strategies to favor rapid transitions to efficient land uses? What are the environmental costs of subsidies to noncompetitive products such as biofuels or extensive grazing, and of government restrictions to efficient systems such as agriculture based on transgenic cultivars or population urbanization including international migration?

The key to successfully confronting the challenges posed by current land-use change is to develop a concept of land-use efficiency that goes beyond the site-oriented approaches favored by most conservation programs. Present efforts to promote production systems with high local biodiversity, but low productivity (e.g., traditional agriculture and grazing, shade coffee, etc.) will not be sufficient to produce agricultural products for a population of more than 9 billion people, which is increasing per capita consumption, without sacrificing large areas of natural ecosystems (Waggoner and Ausubel 2001, Green et al. 2005). To meet the rising global demand for food and conserve Latin American ecosystems, modern high-yield agriculture and agriculture adjustment coupled with rural-urban migration need to be incorporated into large-scale conservation planning (De Fries et al. 2004, Aide and Grau 2004, Balmford et al. 2005, Grau et al. 2008a). 
And, in addition, conservation planning should not be limited to local or regional scales, isolated from the world. Latin American ecosystems protect much of the global biodiversity, but they are also one of the most important regions for global food production. To balance the global demand for food (and potentially biofuels) and at the same time protect the region's biodiversity, it is legitimate for the region to demand that part of the financial costs of preserving these ecosystems be paid by the rest of the world (e.g., Wright 2005). But, at the same time, Latin America can help provide people in Asia, and eventually Africa, the opportunity to improve their nutrition standards, and possibly reduce the pressure on ecosystems in those regions of the world. From a global perspective, if sacrificing part of the natural environment of Latin American can contribute to improving livelihoods in other continents, it may well be worth the sacrifice, in particular, if it eventually results in richer societies around the world with a greater concern for the environment.

Responses to this article can be read online at:

http://www.ecologyandsociety.org/voll3/iss2/art16/responses/

\section{Acknowledgments:}

This project was supported by grants from $\mathrm{FONCYT}$ (Argentina, grants PICT-0 816 and PICT 2006-1693), and NSF (\#0731594 and \#0709598). David Carr, Germán Baldi, Christian Brannstrom, Sandra Baptista, and one anonymous reviewer provided helpful comments on earlier versions of the paper.

\section{LITERATURE CITED}

Achard, F., H. D. Eva, H. J. Stibig, P. Mayaux, J. Gallego, T. Richards, and J. P. Maingreau. 2002. Determination of deforestation rates in the world's humid tropical forests. Science 297:999-1002.

Aide, T. M., and H. R. Grau. 2004. Globalization, migration, and Latin American ecosystems. Science 305:1915-1916

Aragón, R., and J. M. Morales. 2003. Species composition and invasion in NW Argentina secondary forests: effects of land use history, environment and landscape. Journal of Vegetation Science 14:195-204.

Baptista, S. R. 2008. Metropolitanization and forest recovery in southern Brazil: a multiscale analysis of Florianópolis city-region, Santa Catarina state, 1970 to 2005. Ecology and Society 13(2): 5. [online] URL: http://www.ecologyandsociety.org/vol13/iss2/ art5/.

Baldi, G., and J. Paruelo. 2008. Land-use and landcover dynamics in South American temperate grasslands. Ecology and Society 13(2): 6. [online] URL: http://www.ecologyandsociety.org/vol13/iss2/ art6/.

Balmford, A., R. E. Green, and J. P. W. Scharlemann. 2005. Sparing land for nature: exploring the potential impact of changes in agricultural yield on the area needed for crop production. Global Change Biology 11:1594-1605.

Bradley, A., and A. Millington. 2008. Coca and colonists: quantifying and explaining forest clearance under coca and anti-narcotics policy regimes. Ecology and Society 13(1): 31. [online] URL: http://www.ecologyandsociety.org/vol13/iss1/ $\underline{\operatorname{art} 31 /}$.

Bray, D. B., and P. Klepeis. 2005. Deforestation, forest transitions, and institutions for sustainability in southeastern Mexico, 1900-2000. Enviromental History 11:195-223.

Bustamante, R. O., and J. A. Simonetti. 2004. Is Pinus radiata invading native vegetation in central Chile? Demographic responses in fragmented forests. Biological Invasions 7:243-249.

Cavelier, J., and A. Etter. 1995. Deforestation of montane forests of Colombia as a result of illegal plantations of Opium (Papaver somniferum). Pages 541-550 in S. P. Churchill, H. Balslev, E. Forero, and J. L. Luteyn, editors. Neotropical montane forests biodiversity and conservation. The New York Botanical Garden, The Bronx, New York, USA.

Chowdhury, R. R., and B. L. Turner, II. 2006. Reconciling agency and structure in empirical analysis: smallholder land use in southern Yucatán. Annals of the Association of American Geographers 96:302-322. 
De Fries, R., J. Foley, and G. P. Asner. 2004. Land use choices: balancing human needs and ecosystem function. Frontiers in Ecology and the Environment 2:249-257.

Dirzo, R., and P. Raven. 2003. Global state of biodiversity and loss. Annual Review of Environment and Resources 28:137-167.

Dros, J. M. 2004. Managing the soy boom: two scenarios of soy production expansion in South America. Aideenvironment, Amsterdam, The Netherlands.

Ellemberg, H. 1979. Man's influence on tropical mountain ecosystems of South America. Journal of Ecology 67:401-416.

Eva, H. D., A. S. Belward, E. E. de Miranda, C. M. di Bella, V. Gond, O. Hubber, S. Jones, M. Sgranzarolli, and S. Frittz. 2004. A land cover map of South America. Global Change Biology 10:731-744.

Farley, K. A. 2007. Grasslands to tree plantations: forest transition in the Andes of Ecuador. Annals of the Association of American Geographers 97:755771 .

Fearnside, P. M. 2001. Soybean cultivation as a threat to the environment in Brazil. Environmental Conservation 28:23-38.

Fearnside, P. M. 2008. The roles and movements of actors in the deforestation of Brazilian Amazonia. Ecology and Society 13(1): 23. [online] URL: http: //www.ecologyandsociety.org/vol13/iss1/art23/.

Fjdelsa, J., M. D. Alvarez, J. M. Lazcano, and B. León. 2005. Illicit crops and armed conflicts as constraints on biodiversity conservation in the Andes region. Ambio 34:205-211.

Foley, J. A., C. Monfreda, N. Ramankutty, and D. Zaks. 2007. Our share of the planetary pie. Proceedings of the National Academy of Sciences 31:12585-12586.

Food and Agriculture Organization (FAO). 2003. Deforestation hotsopots in the neotropics. FAO, Rome, Italy. [online] URL: http://www.fao.org/ag/ AGAInfo/foto/lead-englow.pdf.

Galindo-Leal, C., and I. De Gusmao Cámara, editors. 2003. The Atlantic forest of South America: biodiversity status, threats and outlook. Island Press, Washington, D.C., USA.

Gasparri, N. I., H. R. Grau, and E. Manghi. 2008. Deforestation, carbon pools, and emissions in Argentine subtropical forests (1900-2005). Ecosystems: in press.

Grau, A. 1985. La expansión del aliso del cerro (Alnus acuminata) en el Noroeste de Argentina. Lilloa 36:237-247.

Grau, H. R., and T. M.Aide. 2007. Are rural-urban migration and sustainable development compatible in mountain systems? Mountain Research and Development 27:119-123.

Grau, H. R., T. M. Aide, J. K. Zimmerman, J. R. Thomlinson, E. Helmer, and X. Zou. 2003. The ecological consequences of socioeconomic and land-use changes in postagricultural Puerto Rico. Bioscience 53:1159-1168.

Grau, H. R., N. I. Gasparri, and T. M. Aide. 2005. Agriculture expansion and deforestation in seasonally dry forests of northwest Argentina. Environmental Conservation 32:140-148.

Grau, H. R., N. I. Gasparri, and T. M. Aide. 2008a. Land use efficiency: balancing food production and nature conservatrion in neotropical dry forests of NW Argentina. Global Change Biology 14:985-997.

Grau, H. R., M. E. Hernandez, N. I. Gasparri, J. Gutierrez, N. I. Gasparri, M. C. Casavecchia, E. E. Flores-Ivaldi, and L. Paolini. 2008b. A periurban neotropical forest transition and its consequences for environmental services. Ecology and Society 13(1): 35. [online] URL: http://www.e cologyandsociety.org/vol13/iss1/art35/.

Grau H. R., M. Perez-Ceballos, S. Martinuzzi, X. Encarnación, and T. M. Aide. 2008c. Cambios socioeconómicos y regeneración del bosque en Republica Dominicana. Pages 211-227 in $\mathrm{M}$. González-Espinosa, J. M. Rey-Benayas, and N. Ramírez-Marcial, editors. Restauración de bosques en América Latina. Mundi-Prensa, México.

Green, R. E., S. J. Cornell, J. P. Scharlemann, and A. Balmford. 2005. Farming and the fate of wild nature. Science 307:550-555. 
Harden, C. 1996. Relationship between land abandonment and land degradation: a case from the Ecuadorian Andes. Mountain Research and Development 16:274-280.

Hecht, S. B. 1993. The logic of livestock and deforestation in Amazonia. Bioscience 43:687-695.

Hecht, S. B., S. Kandel, I. Gomes, N. Cuellar, and H Rosa. 2006. Globalization, forest resurgence, and environmental politics in El Salvador. World Development 34:308-323.

Hecht, S. B., and S. S. Saatchi. 2007. Globalization and forest resurgence: changes in forest cover in $\mathrm{El}$ Salvador. Bioscience 57:663-672.

Hoekstra, J. H., J. M. Boucher, T. H. Ricketts, and C. Roberts. 2005. Confronting a biome crisis: global disparities of habitat loss and protection. Ecology Letters 8:23-29.

Houghton, R. A., D. S. Leftwowitz, and D. C. Skole. 1991. Changes in the landscape of Latin America between 1850 and 1985: I. Progressive loss of forests. Forest Ecology and Management 38:143172.

Intergovernamental Panel for Climate Change (IPCC). 2007. Climate change 2007. The physical science basis. Cambridge University Press, Cambridge, UK.

Izquierdo,A., C. DeAngelo, and T. M.Aide. 2008. Thirty years of human demography and land-use change in the Atlantic Forest of Misiones, Argentina: a test of the forest transition model. Ecology and Society 13(2): 3. [online] URL: http:// www.ecologyandsociety.org/vol13/iss2/art3/.

Izquierdo, A., and H. R. Grau. 2008. Land use and demographic trends across ecoregions of NW Argentina. Journal of Environmental Management: in press.

Jepson, W. A. 2005. A dissapearing biome? Reconsidering land cover change in the Brazilian savanna. Geographical Journal 171:99-111.

Kaimowitz, D. 1995 Livestock and deforestation in Central America in the 1980s and 1990s. A policy perspective. International Food Policy Research Institute, Washington, D.C., USA.
Killeen, T. J., A. Guerra, M. Calzada, L. Correa, V. Calderón, L. Soria, B. Quezada, and M. K. Steininger. 2008. Total historical land-use change in eastern Bolivia: who, where, when, and how much? Ecology and Society 13(1): 36. [online] URL: http://www.ecologyandsociety.org/vol13/iss1/ $\underline{\operatorname{art} 36 / .}$.

Kitzberger, T., and T. T. Veblen. 1999. Fireinduced changes in Patagonian landscapes. Landscape Ecology 14:1-15.

Klink, C. A., and R. B. Machado. 2005. Conservation of the Brazilian Cerrado. Conservation Biology 19:707-713.

Klooster, D. 2003. Forest transition in Mexico. Institutions and forests in a globalized countryside. The Professional Geographer 55:227-240.

Kull, C. A., C. K. Ibrahim, and T. C. Meredith. 2007. Tropical forest transitions and globalization: neo liberlism, migration, tourism and international conservation agendas. Society and Natural Resources 20:723-737.

Lambin, E. F., H. J. Geist, and E. Lepers. 2003. Dynamics of land-use and land-cover change in tropical regions. Annual Review of Environment and Resources 28:205-241.

Laurance, W. F. 1998. A crisis in the making: responses of Amazonian forests to land use and climate change. Trends in Ecology and Evolution 13:411-415.

Lugo, A. E. 2002. Can we manage tropical landscapes? An answer from the Caribbean perspective. Landscape Ecology 17:601-615.

Lugo, A. E., and H. Helmer. 2004. Emerging forests on abandoned land: Puerto Rico's new forests. Forest Ecology and Management 190:145161.

Lutz, W., S. E. D. T. Scherbow, and W. C. Sanderson. 2001. The end of world population growth. Nature 412:543-545.

Mather, A. S. 1992. The forest transition. Area 24:367-379.

Mather, A. S. 2001. The transition from deforestation to reforestation in Europe. Pages 35- 
52 in A. Angelsen and D. Kaimowitz, editors. Agricultural technologies and tropical deforestation CABI Publishing, Wallingford, UK.

Mather, A. S., and C. L. Needle. 1998. The forest transition: theoretical basis. Area 30:117-124.

Millennium Ecosystem Assessment (MEA). 2005. Ecosystems and human well-being: biodiversity synthesis. World Resource Institute, Washington, D.C., USA. [online] URL: http://www .millenniumassessment.org/documents/document.354. aspx.pdf.

Morales, M. M., R. Villalba, and J. J. Boninsegna. 2005. Climate, land-use and Prosopis ferox recruitment in the Quebrada de Humahuaca. Dendrochronologia 22:169-174.

Moran, E. F., A. Packer, E. Brondizio, and J. Tucker. 1996. Restoration of the vegetation cover in the eastern Amazon. Ecological Economics 18:41-54.

Nepstad, D. C., A. Verissimo, A. Alentar, C. Nobre, E. Lima, P. Lefevre, P. Schlezinger, C. Potter, P. Moutinho, E. Mendoza, M. Cochrane, and V. Brooks. 1999. Large-scale impoverishment of Amazonian forests by logging and fire. Nature 398:505-508.

Nossetto, M. D., E. G. Jobbággy, and J. M. Paruelo. 2005. Land-use change and water losses: the case of grassland afforestation accross a soil texture gradient in central Argentina. Global Change Biology 11:1001-1017.

Padoch, C., E. Brondizio, S. Costa, M. PinedoVasquez, R. R. Sears, and A. Siqueira. 2008. Urban forest and rural cities: multi-sited households, cunmsumption patterns, and forest resources in Amazonia. Ecology and Society 13(2): 2. [online] URL: http://www.ecologyandsociety.org/ vol13/iss2/art2/.

Pan, W., D. Carr, A. Barbieri, R. Bilsborrow, and C. Suchindran. 2007. Forest clearing in the Equadorian Amazon: a study of patterns over space and time. Population Research and Policy Review 26: 635-659.

Parés-Ramos, I., T. M. Aide, and W. Gould. 2008. Agricultural abandonment, suburban growth, and forest expansion in Puerto Rico between 1991 and 2000. Ecology and Society 13(2): 1. [online] URL: http://www.ecologyandsociety.org/vol13/iss2/art1/

Paruelo,J. M., and M. Oesterheld. 2005. Patrones temporales y espaciales de la expansión de la soja en la Argentina. Relación con factores socioeconómicos y ambientales. Argentina Rural Strategy, World Bank, IFEVA, Buenos Aires, Argentina.

Perz, S. G., and D. L. Skole. 2003. Secondary forest expansion in the Brazilian Amazon and the refinement of forest transition theory. Society and Natural Resources 16:277-294.

Polèse, M. 1998. Economía urbana y regional. Introducción a la relación entre territorio $y$ desarrollo. Libro Universitario Regional, Cartago, Costa Rica.

Preston, D. 1997. People on the move: migrations past and present. Pages 165-187 in D. Preston, editor. Latin American development. Geographical perspectives. Longman, Singapore.

Preston D. 1998. Post peasant capitalist grazersthe $21^{\text {st }}$ century in southern Bolivia. Mountain Research and Development 18:151-158.

Preston, D., M. Macklin, and J. Warburton. 1997. Fewer people, less erosion: the twentieth century in southern Bolivia. The Geographical Journal 163:198-205.

Ramankutty, N., and J.A. Foley. 1999. Estimating historical changes in global land cover: croplands from 1700 to 1992. Global Biogeochemical Cycles 13:997-1027.

Rudel, T. K., D. Bates, and R. Machiguiashi. 2002. A tropical forest transition? Agricultural change, outmigration, and secondary forests in Ecuadorian Amazon. Annals of the Association of American Geographers 92:87-102.

Rudel, T. K., O. T. Coomes, E. Moran, F. Achard, A. Angelsen, J. Xu, and E. Lambin. 2005. Forest transitions: towards a global understanding of the land use change. Global Environmental Change 15:2331. 
Sader, S. A., and A. T. Joyce. 1988. Deforestation rates and trends in Costa Rica, 1940 to 1983. Biotropica 20:11-19.

Silva, J. F., M. R. Fariñas, J. M. Felfili, and C. A. Klink. 2006. Spatial heterogeneity, land use and conservation in the Cerrado region of Brazil. Journal of Biogeography 33:536-548.

Smil, V. 2000. Feeding the world: a challenge for the twenty-first century. MIT Press, Boston, Massachusetts, USA.

Southworth, J., and C. Tucker. 2001. The influence of accesibility, local institutions, and socioeconomic factors on forest cover change in the mountains of Western Honduras. Mountain Research and Development 21:276-283.

The World Bank. 2006. Global economic prospects: economic implications of remmittances and migration. The World Bank, Washington, D. C., USA.

United Nations Population Fund (UNFPA). 2007. State of the world population. Unleashing the potential of urban growth. [online] URL: http://ww w.unfpa.org/swp/swpmain.htm.

United Nations Population Division (UNPOP). 2003. World population prospects: the 2002 revision: highlights. UNDP, New York, New York, USA.

Viglizzo, E. F., F. C. Frank, and L. Carreño. 2006. Situación ambiental en las ecoregiones Pampa y Campos y Malezas. Pages 263-273 in A. D Brown, U. Martinez-Ortiz, M. Acerbi, and J. Corcuera, editors. Situación ambiental Argentina 2005. Fundación Vida Silvestre, Buenos Aires, Argentina.

Vitousek P. M., P. R. Ehrlich, A. H. Ehrlich, and P. A. Matson. 1986. Human appropriation of the products of photosynthesis. Bioscience 36:368373.

Viña A., and J. Cavelier. 1999. Deforestation rates (1938-1988) of tropical lowland forests on the Andean foothills of Colombia. Biotropica 31:3138.

Waggoner, P. E., and J. H. Ausubel. 2001. How much feeding more and wealthier people will encroach on forests? Population and Development Review 27:239-257.
Wiegers, E. S., R. J. Hijmans, D. Herve, and L. O. Fresco. 1999. Land use intensification and disintensification in the Upper Cañete Valley, Peru. Human Ecology 27:319-339.

Wright, S. J. 2005. Tropical forests in a changing environment. Trends in Ecology and Evolution 20:553-560.

Wright, S. J., and M.Samaniego. 2008. Historical, demographic and economic correlates of land-use change in the Republic of Panama. Ecology and Society 13(2): 17. [online] URL: http://www.ecolog yandsociety.org/vol13/iss2/art17/.

Zak, M. R., M. Cabido, and J. G. Hodgson. 2004. Do subtropical seasonal forests in the Gran Chaco, Argentina, have a future? Biological Conservation 120:589-598.

Zimmerer, K. S. 1993. Soil erosion and labor shortage in the Andes with special reference to Bolivia, 1953-1991. World Development 21:16591675. 